\title{
Biology of mistletoes and their status in Nepal Himalaya
}

\author{
Mohan Prasad Devkota \\ Amrit Science Campus, Tribhuvan University, Kathmandu, NEPAL \\ For correspondence,E-mail:mdevkota@wlink.com.np
}

The mistletoes constitute a polyphyletic group of flowering parasitic plants and are commonly known as "Ainjeru" or "Lisso" in Nepali. Of the over 1300 mistletoe species occurring worldwide, Nepal is home to 19. Mistletoes are entirely dependent on their hosts for water and nutrients and affect their hosts mainly by competing for limited resources. Mistletoes play a vital role in natural plant communities by interacting with hosts, herbivores and dispersers. A large number of invertebrates and vertebrates use mistletoes as a shelter, as nesting and roosting place and as an important source of food. Oddly, botanists have accorded little attention to Nepal's mistletoes, and our knowledge of this remarkable group of plants is quite deficient.

Himalayan J ournal of Sciences 3(5): 85-88, 2005

Available online at: www.himjsci.com
Received: 23 Dec 2004

Accepted after revision: 18 May 2005
Copyright $\odot 2005$ by Himalayan Association for the Advancement of Science (HimAAS)
Mistletoe (order: Santalales) refers to a group of perennial flowering plants attached to branches of other trees and shrubs as aerial parasites (Barlow 1987, Kuijt 1990). The name 'mistletoe' derives from the Anglo-Saxon misteltan (or mistiltan); 'mistel' meaning dung, and 'tan' meaning twig. Thus it literally means 'dung-on-a-twig' (Calder 1983). Taxonomically, the mistletoes constitute a highly specialized and diverse group of angiosperms. They are obligate stem parasites whose dependency ranges from holoparasitic to hemiparasitic, and they are characterized by the development of a haustorium, an absorptive organ that serves as a sort of root, attaching to the host and penetrating its conductive tissues in order to pass nutrients to the parasite.

\section{Diversity}

Despite a large number of botanical explorations in Nepal, biologists have made scanty collection of mistletoe specimens. The heterogeneous geomorphology of the Himalayas and the rich floral diversity offers a good habitat for a variety of mistletoe species. In their comprehensive catalogue of Nepalese flowering plants, Hara et al. (1982) mentioned 12 mistletoe species belonging to six genera of Loranthaceae and three species belonging to two genera of Viscaceae. While this number has been confirmed by recent publications (Press et al. 2000 and HMGN 2001). Devkota and Glatzel (2005) and Devkota and Koirala (2005) have reported four species new to Nepal: Viscum multinerve Hayata, V. loranthi Elmer and V. moniocum Roxb ex DC (family Viscaceae), and Scurrula gracilifolia (Schult.) Danser (family Loranthaceae), extending the list of mistletoe species to 19.

Grierson and Long (1983) have reported 15 mistletoe species belonging to Loranthaceae and six species of Viscaceae in Bhutan. Apart from some scattered data (e.g., Zakaullah 1977, Zakaullah and Khan 1982), no information on mistletoe diversity is available from Western Himalayas. However, over 1300 species have been reported from the world (Table 1).

\section{Biogeography}

Mistletoe families Loranthaceae and Viscaceae have separate geographic origins and different cytological history (Barlow 1983). Loranthaceae are older than the Viscaceae; they originated in the mesic, warm to mild, closed forest of Cretaceous Gondwana, dispersing subsequently to Africa, Europe, and North America (Barlow 1983). The parasitic habit did not arise as a response to water stress but rather due to competition for nutrients in complex ecosystems (Barlow 1983). The youngerViscaceae, previously considered to have a Laurasian origin in the Tertiary period (Barlow 1983), are now believed also to have originated in Gondwana (Barlow 1987). Nearly all mistletoe genera are exclusively tropical or subtropical and only a handful of species are found elsewhere (Kuijt 1969). The Loranthaceae and Viscaceae are presently distributed widely throughout Europe, the Americas, Africa, Asia, and Australia, ranging from boreal climate to temperate, tropical, and arid zones, and absent only from extremely cold regions (Barlow 1983, Kuijt 1969). The Loranthaceae is distributed primarily in tropical and south temperate habitats; Africa, Indomalaya-Australia, and South America are the major centers of diversity. The Viscaceae are also widespread in the tropics but extend further towards the northern temperate zone (Barlow 1987).

\section{Host range}

Mistletoes are found on a wide range of woody plants, from forest trees, avenue trees, fruit trees and ornamental trees to shrubs, thorny scrubs, euphorbs and cacti. Mistletoes preferentially parasitize trees and shrubs, and their greatest diversity is found in forests and woodlands (Kuijt 1969, Calder 1983, Hawksworth 1983). They prefer disparate hosts in diverse biomes: conifers in boreal forests (Hawksworth 1983, Hawksworth and Wiens 1996), succulent euphorbs and cacti in the African and South American deserts (Martinez del Rio et al. 1996, Polhill andWiens 1998), monocots and bracken ferns (Fineran and Hocking 1983) and orchids (Kuijt and Mulder 
1985) in tropics. Many individual mistletoe species are capable of parasitizing a large number of host species (Table 2).

\section{Distribution pattern}

The distribution of mistletoes in natural plant communities is not uniform, being affected by many local environmental factors. Mistletoes spread mainly along roadsides, riverbanks, in the vicinity of fields and villages, in orchards, on warm slopes and in forests (Zakaullah and Khan 1982, Xiao and Pu 1988, Lopez et al. 2002, Devkota 2003). Hawksworth (1959), Ganguly and Kumar (1976) and Zakaullah (1977) reported the highest frequency of mistletoes on ridges; fewer were found on slopes and fewest on the plains. The high density of mistletoe on ridges is due to the presence of ample light intensity (Ganguly and Kumar 1976, Lopez et al. 2002). Distribution of mistletoes in the Annapurna Conservation Area, is impacted by three major factors: forest structure, site mesoclimate and zoocore dispersal (Devkota 2003). The distribution of host trees and the behavior of avian visitors seem to be primary factors determining the distribution of mistletoes in Kathmandu Valley (Devkota and Acharya 1996). Kuijt (1969) concludes that mistletoe distribution depends entirely upon the habits of the birds that disseminate the seeds.

\section{Mistletoe-host interaction}

Mistletoes affect host viability by withdrawing essential resources. The parasite competes with its host for water, inorganic nutrients and organic compounds. The extent to which the host is affected depends not only on how much of the resource is diverted by the parasite, but also on the overall supply available to the host (Graves 1995). Some leafy mistletoe may live for decades in association with their host trees and result in little apparent damage (Schulze and Ehleringer 1984), while others inflict severe damage.

Mistletoes affect hosts in many ways, including reduced growth, diminished vigor, premature mortality, impaired quality and quantity of wood, reduced fruit set, and heightened susceptibility to attack by other agents such as insects or fungi. When one part of the host is intensively attacked by mistletoe, the reproductive and photosynthetic potential of the part distal to the infestation declines leading to death of the part (Kuijt 1969). But the extent of damage caused to the host depends on size of the parasite, the growth rate and metabolic activity of the parasite, the degree of dependency on the host for resources, and the stage of development of the host (Hawksworth 1983). In Australia, however, Race and Stelling (1997) did not find a significant correlation between the health of individual host plants and the number of mistletoe plants afflicting them; they concluded that mistletoe may not necessarily be harmful to its host.

\section{Mineral nutrition}

While mistletoes are entirely dependent on their hosts for water and nutrients (Glatzel 1983, Popp and Richter 1998), they differ greatly in the extent to which they rely on the supply of photosynthetic products from their hosts. The extent to which mistletoes depend on heterotrophic carbon input from the host is one of the most important aspects in the mistletoe nutrition.

Xylem tapping mistletoes are capable of fixing atmospheric carbon dioxide and are therefore partially heterotrophic; others also parasitize phloem of their hosts and are regarded as holoparasites. The latter group lacks chlorophyll or has reduced photosynthetic organs, whereas the xylem parasites are regarded as 'obligate hemiparasitic' as they rely only partially on host-derived carbon (Tsivion 1978). The xylem tapping mistletoes have a higher transpiration rate than their host, as a mechanism to draw sufficient nutrients from the host xylem sap. Since there is no phloem connection between host and such mistletoes, retranslocation of excess nutrients back to the host cannot occur. As a result, mistletoe tissues accumulate higher concentrations of nutrient elements than those of their hosts (Glatzel 1983, Devkota 2003).

\section{Mutualism involving mistletoes and birds}

Many bird species are intricately involved in the life cycle of mistletoes especially in pollination and seed dispersal (Kuijt 1969, Barlow 1983, Reid 1991, Ladley and Kelly 1995a). The establishment of the host-mistletoe association cannot be examined without understanding the role of seed-dispersing birds, especially the frugivores. The feeding habits of the birds and the duration of seed retention within their body determine the successful dispersal of the mistletoes.

Old world sunbirds (Nectariniini), Oriental flowerpeckers (Dicaeini) and white-eyes (Zosterops), Australian honeyeaters (Meliphagidae), and neotropical humming birds (Trochilidae) are the most common avian pollinators (Docters van Leeuwen 1954, Gill and Wolf 1975, Reid 1986). Studies by Ali (1931) and Davidar $(1978,1983,1985$ and 1987) in the Oriental region have shown that the sunbirds and the flowerpeckers, when foraging for nectar, probe mistletoe flowers in distinct ways, thus effecting pollination.

Most Loranthacean species have fleshy, animal-dispersed single-seeded fruits (Kuijt 1969, Johri and Bhatnagar 1972), which are an important source of food for many bird species worldwide (Docters van Leeuwen 1954, Kuijt 1969, Reid 1986, Watson 2001). Small frugivorous birds that feed largely on the fruits of mistletoes have evolved independently several times in different parts of the world and are the major fruit consumers and most effective dispersers of their fruit (Ali 1931, Dowsettlemaire 1982, Davidar 1983, Liddy 1983, Godschalk 1985). For the mistletoes, where germination is entirely dependent on bird dispersal to remove the exocarp, Ladley and Kelly (1996) conclude that while the current population of sunbirds and flowerpeckers does not appear to threaten mistletoes survival, the role of the dispersers needs to be considered when pursuing mistletoes conservation assessment.

\section{Reproduction}

Sexual reproduction in a large number of mistletoe species is influenced by birds, which play a significant role in their pollination and dispersal. Most Loranthaceous mistletoes have large, brightly colored, hermaphroditic flowers, which produce abundant nectar and are bird-pollinated (Kuijt 1969). Ali (1931) concludes that the propagation strategy of mistletoe is so inextricably linked to the behavior of sunbirds and flowerpeckers that they would soon die out altogether in the absence of the birds. Viscaceous mistletoes are pollinated by insects (hymenopterans) or wind (Kuijt 1969), but birds are also important in seed dispersal. In a large number of Loranthaceae and Viscaceae species the succulent fruit pulp (mesocarp) contains nutrients to attract avian dispersers, and endocarp is viscous in order to cement the seed on host branch. Some Viscaceous genera (Arceuthobium and Korhalsella) are dispersed locally by fruits with explosive mechanisms; however, they may also be dispersed over long distances when the seeds stick to the plumage or pelage of birds and mammals (Barlow 1983). 
TABLE 1. Number of genera and species of Mistletoe in the world and in Nepal

\begin{tabular}{lllll}
\hline Family & World* & \multicolumn{3}{c}{ Nepal** } \\
\cline { 2 - 5 } & Genera & Species & Genera & Species \\
\hline Loranthaceae & 74 & 910 & 6 & 13 \\
\hline Misodendraceae & 1 & 8 & & \\
\hline Santalaceae & 7 & 51 & & 6 \\
\hline Viscaceae & 7 & ca 350 & 2 & 19 \\
\hline Total & 89 & ca. 1319 & $\mathbf{8}$ & 19 \\
\hline
\end{tabular}

Source: *Nickrent 2002; **Hara et al. 1982, Devkota and Glatzel 2005a,

Devkota and Koirala 2005b

TABLE 2. Number of host species for some important mistletoe species

\begin{tabular}{lll}
\hline Mistletoe species & $\begin{array}{l}\text { Number of host } \\
\text { species }\end{array}$ & References \\
\hline Dendrophthoe falcata & $\begin{array}{l}401 \text { (227 genera and } \\
77 \text { families) }\end{array}$ & $\begin{array}{l}\text { Hawksworth et al. } \\
(1993)\end{array}$ \\
\hline $\begin{array}{l}\text { Macrosolen } \\
\text { cochinchinensis }\end{array}$ & 27 (23 genera) & Ganguly and Pal (1975) \\
\hline Scurrula elata & $\begin{array}{l}48 \text { (40 genera and 26 } \\
\text { families) }\end{array}$ & Devkota (2003) \\
\hline Scurrula parasitica & $\begin{array}{l}38 \text { (30 genera and 22 } \\
\text { families) }\end{array}$ & Devkota (2005) \\
\hline Scurrula pulverulenta & $\begin{array}{l}81 \text { (58 genera and 34 } \\
\text { families) }\end{array}$ & Pundir (1995) \\
\hline Viscum album & $\begin{array}{l}452 \text { (96 genera and 44 } \\
\text { families) }\end{array}$ & Barney et al. (1998) \\
\hline
\end{tabular}

Seed dispersal depends primarily on animals, which are attracted by the colorful fruits or fleshy appendages. Insects are the main pollinators of the Santalaceae, but humming birds also are pollinating agents for two South African genera (Kuijt 1969). Among the Santalaceae, bird dispersal predominates (Kuijt 1969), but ants are also important dispersal agents. The pollination biology of the Misodendraceae is less well understood. Single-seeded fruit (achene), with three barbed awn and a sticky disc at the radical end of Misodendraceous mistletoes plants are dispersed by wind.

\section{The misunderstood mistletoes}

Several studies in the past have concluded that mistletoes are an important structural and functional component of forests and woodland communities. The common opinion that mistletoes are destructive weeds should be challenged. Due to their parasitic nature, mistletoes have been considered invasive pests, and as a detriment to forest health by policy makers, foresters, forest owners, lay people and even biologists. Mistletoes need to be promoted as indicators of habitat health, rather than agents of destruction; as Ladley and Kelly (1996) and Watson (2001) suggested, they should be "considered a keystone resource in woodlands and forests, having a disproportionate influence on the distribution patterns of animals." Besides having profound consequences for those species associated with their hosts, mistletoe infection can also have a strong impact on the larger communities in which it occurs by (for instance) altering forest structure and composition (Geils and Hawksworth 2002).
Compared to those of the NewWorld, OldWorld mistletoes are under-represented in the mistletoe literature despite their dominating presence in highly diverse ecosystems from tropics to temperate. The role of mistletoes in the biodiversity of the Himalayas is unexplored, and it is unknown how mistletoes affect biodiversity. There is very little information available on the mistletoes of the Nepal Himalaya; most reports come from the Western Himalayas of India and Pakistan, and a few from the Southern parts of India (Ali 1936, Davidar 1978).

\section{Potential threats to mistletoes of Nepal Himalayas}

The broad-leaved forests of the temperate region (2000-3000 masl) constitute the most suitable habitat for mistletoes in Nepal (Devkota 2003). Nepal's forests, unfortunately, are facing severe stress due to increasing demand for agricultural land, timber, fuelwood and fodder, and to encroachment of settlements on forest areas. The most critical threat to biodiversity is habitat destruction (HMGN/MFSC 2002). Deforestation and land degradation are serious problems in Nepal and major threats to the natural populations of mistletoes. Other threats include depredation by insects and fungal disease; vegetation succession; pressure on bird species that serve as mistletoe pollinators and disseminators; collection of mistletoe for fodder during the flowering and fruiting seasons; and, in general, human negligence of a group of plants incorrectly identified as pests.

\section{Management requirements}

Despite their parasitic nature, the mistletoes play important roles in natural ecosystems. Regardless of the National Biodiversity Strategy (HMGN/MFSC 2002), policy makers of Nepal have failed to recognize the importance of mistletoes in biodiversity conservation. As an initial step, we need a nationwide study of the current status of mistletoe, including identification of the host range of individual mistletoe species. The government of Nepal should take the initiative in designing and implementing an action plan to protect mistletoes; Tribhuvan University, IUCN, ICIMOD, andWWF Nepal, should be involved as well. Mistletoe conservation can be initiated by adopting the following measures:

\section{Immediate protection measures}

- Conduct mistletoe inventories throughout the country, especially in all protected areas, with a view to conservation management and identify the potential mistletoe habitats,

- Restore and reforest potential habitats especially in broadleaf forests at middle elevation,

- Impose strict rules against fodder collection and tree felling in potential habitats,

- Stop agricultural expansion and grazing in and around potential habitats.

Long term conservation action plan

- Develop a long-term mistletoe conservation plan for Nepal,

- Continue to monitor mistletoe population in their potential habitats; establish and maintain a mistletoe database of Nepal,

- Control human induced disturbance, set the forest resources for natural regeneration and discourage the use and introduction of alien species,

- Control pests affecting mistletoes. 


\section{ARTICLES}

\section{References}

Ali S. 1931. The role of sunbirds and flower peckers in the propagation and distribution of the tree parasite, Loranthus longiflorus Dest., in the Konkan (W. India). Journal of Bombay Natural History Society 25 142-149

Ali S. 1936. The Ornithology of Travancore and Cochin. Journal of Bombay Natural History Society 38: 759-790

Barlow BA. 1983. Biogeography of Loranthaceae andViscaceae. In: Calder M and P Bernhardt (eds), The Biology of Mistletoes, Australia: Academic Press. p 19-46

Barlow BA. 1987. Mistletoes. Biologist 34: 261-269

Barney CW, FG Hawksworth and BW Geils. 1998. Hosts of Viscum album. European Journal of Forest Pathology 28: 187-208

Calder M. 1983. Mistletoes in Focus: An Introduction. In: Calder M and P Bernhardt (eds), The Biology of Mistletoes. Australia: Academic Press. p $1-18$

Davidar P. 1978. Dispersal in some Loranthaceae of the Nilgiris. Journal of Bombay Natural History Society 75: 943-945

Davidar P. 1983. Similarity between flowers and fruits in some flower pecker pollinated mistletoes. Biotropica 15:32-37

Davidar P. 1985. Ecological interactions between mistletoes and their avian pollinators in south India. Journal of Bombay Natural History Society 82: $45-60$

Davidar P. 1987. Fruit structure in two neotropical mistletoes and its consequences for seed dispersal. Biotropica 19: 137-139

Devkota MP. 2003. Mistletoes of the Annapurna Conservation Area of the central Nepal Himalayas - Diversity, distribution and biology [PhD dissertation]. Vienna, Austria: University of Natural Resources and Applied Life Sciences. $159 \mathrm{p}$

Devkota MP and G Glatzel. 2005. Mistletoes of Annapurna Conservation Area, Central Nepal Himalayas. Journal of Japanese Botany 80(1): 27-36

Devkota MP and A Koirala. 2005. New record of mistletoe Viscum monoicum Roxb. ex DC. (Viscaceae) for the Nepal Himalayas. Journal of Japanese Botany 80(1): 56

Devkota MP. 2005. Ecological interaction between mistletoes and their avian partners of Godawari area, Nepal. A report submitted to University Grant Commission, Kathmandu, Nepal. 39 p

Devkota MP and N Acharya. 1996. Mistletoes (Loranthaceae andViscaceae) in the Kathmandu valley, Nepal: Altitudinal distribution, Host trees, Pollinators and Seed dispersers. Acta Phytotaxonomica et Geobotanica 47(2): 213-219

Docters Van Leeuwen WM. 1954. On the biology of some Javanese Loranthaceae and the role birds play in their life histories. Beaufortia 4: 105-207

Dowsett-Lemaire F. 1982. Tinkerbird and mistletoes on the Nyika Plateau, South Central Africa. The Golden Bough 1: 3

Fineran BA and PJ Hocking. 1983. Features of parasitism, morphology and haustorial anatomy in Loranthaceous root parasites. In: Calder M and P Bernhardt (eds), The Biology of Mistletoes. Australia: Academic Press. p 205-227

Ganguly P and D Pal. 1975. Some notes on the distribution, nature of hosts and symptoms of a flowering parasite, Macrosolen cochinchinensis in West Bengal. Journal of Bombay Natural History Society 72: 883-886

Ganguly P and NC Kumar. 1976. Topographical distribution of the phanerogamic parasites in Sukna forest, Darjeeling District, West Bengal. Indian Forester 102: 459-462

Geils BW and FG Hawksworth. 2002. Damage, effects, and importance of dwarf mistletoes. In: Mistletoes of North American conifers. USA: Forest Service, U.S. Department of Agriculture. p 57-65

Gill FB and LLWolf. 1975. Foraging strategies and energetics of east African sunbirds at mistletoe flowers. American Naturalist 109: 491-510

Glatzel G. 1983. Mineral nutrition and water relations of hemiparasitic mistletoes: A question of partitioning. Experiments with Loranthus europaeus on Quercus petraea and Quercus robur. Oecologia 56: 193-201

GodSchalk SKB. 1985. Feeding behaviour of avian dispersers of mistletoe fruit in the Loskop Dam Nature Reserve. South Africa. South African Journal of Zoology 20:136-146

Graves JD. 1995. Host plant responses to parasitism. In: Press MC and JD Graves (eds), Parasitic Plants. London: Chapman and Hall. p 206-225

Grierson AJC and DG Long. 1983. Flora of Bhutan, Vol.1, part I. Edinburgh: Royal Botanical Garden. p 143-155

Hara H, AO Chater and LHJWilliams. 1982. An enumeration of flowering plants of Nepal, Vol. III. London: British Museum (Natural History). $226 \mathrm{p}$

Hawksworth FG. 1959. Distribution of dwarf mistletoes in relation to topography on the Mesacalaro Apache Reservation. New Mexico. Journal of Forestry 57: 919-922
Hawksworth FG. 1983. Mistletoes as forest parasites. In: Calder M and P Bernhardt (eds), The Biology of Mistletoes. Australia: Academic Press. p 317-333

Hawksworth FG, YPS Pundir, CG Shaw and BW Geils. 1993. The host range of Dendroepthoe falcata (L. f.) Etttings (Loranthaceae). Indian Journal of Forestry 16(3): 263-281

Hawksworth FG and D Wiens. 1996. Dwarf mistletoe: biology, pathology, and systematics. Agricultural handbook 709. Washington DC: U.S Department of Agriculture, Forest Service. $410 \mathrm{p}$

HMGN. 2001. Flowering plants of Nepal (Phanerogams). Kathmandu: Ministry of Forest and Soil Conservation, HMGN. 399 p

HMGN/MFSC. 2002. Nepal Biodiversity Strategy. Kathmandu: Ministry of Forest and Soil Conservation, HMGN. $170 \mathrm{p}$

Johri BM and SP Bhatnagar. 1972. Loranthaceae. Botanical Monograph No. 8. New Delhi: Council of Scientific and Industrial Research. $155 \mathrm{p}$

Kuijt J. 1969. The Biology of Parasitic Flowering Plants. Los Angeles: University of California Press. $246 \mathrm{p}$

Kuijt J. 1990. Correlations in the germination pattern of Santalaceae and other mistletoes. In: Bass P, K Kalkman and R Geesink (eds), Plant Diversity of Malaysia. Proceedings of the Flora Malaysian Symposium Commemorating Prof. Dr. C.G.G.J. van Steenis. The Netherlands: Kluwer Academic Publisher. p 63-72

Kuijt J and D Mulder. 1985. Mistletoes parasitic on Orchids. American Orchid Society Bulletin 54: 976-979

Ladley JJ and D Kelly. 1995. Explosive New Zealand mistletoe. Nature 378: 766

Ladley JJ and D Kelly. 1996. Dispersal, germination and survival of New Zealand mistletoes (Loranthaceae) : Dependence on birds. New Zealand Journal of Ecology 20: 69-79

Liddy J. 1983. Dispersal of Australian mistletoe : The Cowiebank study. In: Calder M and P Bernhardt (eds), The Biology of Mistletoes. Australia: Academic Press. p 101-116

Lopez De Buen L, JF Ornelas and JG Garcia Franco. 2002. Mistletoe infection of trees located at fragmented forest edges in the cloud forests of Central Veracruz, Mexico. Forest Ecology and Management 164: 293-302

Martinez del Rio C, M Hourdiquin, A Silva and R Mendel. 1996. Seed dispersers as disease vectors: Bird transmission of mistletoe seeds to plant host. Ecology 77: 912-921

Nickrent DL. 2002. Parasitic Plants of theWorld. In: López-Sáez JA, P Catalán and L Sáez (eds), Parasitic Plants of the Iberian Peninsula and Balearic Islands. Madrid: Mundi-Prensa. p 7-27

Polhill R and DWiens (eds). 1998. Mistletoes of Africa. London: The Royal Botanic Garden. 370 p

Popp M and A Richter. 1998. Ecophysiology of Xylem-tapping mistletoes. Ecology and Vegetation Science 59: 659-674

Press JR, KK Shrestha and DA Sutton. 2000. Annotated checklist of the flowering plants of Nepal. London: The Natural History Museum. 430

Pundir YPS. 1995. Host range of Scurrula pulverulenta (Wall.) G. Don. Loranthaceae from Dun valley and adjacent areas. Indian Journal of Forestry 18: 74-79

Race D and F Stelling. 1997. Mistletoe ecology in Melbourne's bush land. The Victorian Naturalist 114(3): 122-126

Reid N. 1986. Pollination and seed dispersal of mistletoes (Loranthaceae) by birds in Southern Australia. In: Ford HA and DC Patton (eds), The dynamic partnership, birds and plants in Southern Australia. South Australia: Government Publisher. $199 \mathrm{p}$

Reid N. 1991. Coevolution of mistletoes and frugivorous birds. Australian Journal of Ecology 16: 457-469

Schulze ED and JR Ehleringer. 1984. The effect of Nitrogen supply on growth and water use efficiency of xylem-tapping mistletoes. Planta 162: 268275

Tsivion Y. 1978. Physiological concepts of the association between parasitic angiosperms and their hosts - a review. Israel Journal of Botany 27: 103-121

Watson DM. 2001. Mistletoe-A key stone resource in forests and woodlands worldwide. Annual Reviews of Ecological Systems 32: 219-249

Xiao L and Z Pu. 1988. An exploration of the Loranthaceae in Xishuanghanna. Acta Botanica Yunnanica 10: 69-78

Zakaullah. 1977. Survey of Juniper dwarf mistletoe in the adjacent areas of Sasnamana State forest of Baluchistan. The Pakistan Journal of Forestry 27(3): 143-146

Zakaullah and MH Khan. 1982. Survey and control of mistletoes in Pakistan. Peshawar: Pakistan Forest Institute. Annual Technical Report. Project PK-FS-55. $11 \mathrm{p}$ 